\title{
PENGEMBANGAN JADWAL SHIFT STAF EDITOR VIDEO PADA STASIUN TELEVISI NASIONAL TRANS7 BERBASIS ANDROID MENGGUNAKAN ALGORITMA ANT COLONY DENGAN FIREBASE
}

\author{
Rizal*1 $^{* 1}$ Eliyani $^{2}$ \\ 1,2Program Studi Teknik Informatika, Fakultas Ilmu Komputer, Universitas Mercu Buana \\ Email: ${ }^{14} 1516120070 @$ student.mercubuana.ac.id, ${ }^{2}$ eliyani@mercubuana.ac.id \\ *Penulis Korespondensi
}

(Naskah masuk: 10 Desember 2018, diterima untuk diterbitkan: 06 Februari 2020)

\begin{abstract}
Abstrak
Perusahaan bisnis bidang broadcasting atau tepatnya stasiun televisi memiliki strategi untuk menayangkan tayangan acara yang paling ditunggu oleh penonton setianya, yaitu berupa tayangan acara yang up to date dan cepat dalam penyiarannya. Oleh sebab itu, diperlukan staf pada bagian pasca produksi untuk bekerja secara cepat dan sesuai dengan prosedur tayangan. Untuk mempersiapkan tayangan terbaru secara cepat, diperlukan sistem penjadwalan staf editor video yang jumlahnya besar secara cepat, tepat, dan dapat dilihat dengan instan oleh para editor video sehingga memudahkan editing video setiap harinya. Algoritma yang cocok untuk menghasilkan jadwal secara cepat dengan jumlah yang besar dengan tidak ada data yang bentrok adalah ant colony atau algoritma koloni semut. Algoritma ant colony ini mengacu pada cara hidup semut yang berkelompok dalam mencari makanan sehingga dapat kembali lagi ke tempat semula dengan jalur yang sama dan cepat. Data masukan yang digunakan dalam penelitian ini adalah nama editor dan ruangan, serta luaran berupa jadwal per shift untuk setiap ruangan untuk suatu periode tertentu. Penelitian ini menggunakan basis data MySQL dan firebase. Jadwal editor yang telah diolah pada aplikasi back-end kemudian diubah ke dalam bentuk aplikasi android, dengan demikian jadwal tersebut dapat dilihat oleh seluruh staf editor video melalui smartphone masing-masing. Pengujian dilakukan terhadap hasil perhitungan algoritma, fungsional sistem, integrasi, dan penerimaan yang dikembalikan pada sistem dengan mencari kesalahan pada interface perangkat lunak, dan pengujian penggunaan langsung kepada pengguna. Hasil pengujian menunjukkan bahwa algoritma ant colony dapat digunakan untuk menyusun jadwal editor video dengan cepat dan tepat, semua fitur berjalan dengan baik, dan tingkat kepuasan pengguna cukup tinggi.
\end{abstract}

Kata kunci: jadwal, ant colony, android, firebase, edit

\section{DEVELOPMENT OF VIDEO EDITOR SHIFT SCHEDULE ON ANDROID BASED TRANS7 NATIONAL TELEVISION USING ANT COLONY ALGORITHM WITH FIREBASE}

\begin{abstract}
Broadcasting or television business companies have a strategy to broadcast programs up to date and quickly. Therefore, staff in the post-production section are required to work quickly and in accordance with the show procedures. To prepare the latest shows quickly, a video editor staff scheduling system is needed. That scheduling system should be fast, precise, and can be seen instantly by video editors so that the editing processes can be done easily every day. The suitable algorithm to generate a schedule quickly in large numbers with no data clashing is ant colony. Ant colony algorithm refers to the way of ants when looking for food in a group, then they can return again to their original place with the same path and fast. The input data used in this study is the name of the editor and the room, and output in the form of a schedule per shift for each room for a certain period. This research uses MySQL and firebase databases. The editor's schedule that has been processed in the back-end application is then converted into an android application, therefore the schedule can be seen by all video editor staff via their own smartphones. Tests are carried out on the results of algorithm calculations, functional systems, integration, and feedback to the system by looking for errors on the software interface, and direct use testing to users. The test results show that the Ant Colony algorithm can be used to compile a schedule of video editors quickly and precisely, all features run well, and the level of user satisfaction is quite high.
\end{abstract}

Keywords: schedule, ant colony, android, firebase, edit 


\section{PENDAhUluAN}

Sebagai perusahaan yang menayangkan berita maupun konten hiburan ke seluruh nusantara, perusahaan televisi nasional dituntut untuk senantiasa menayangkan video yang terbaru. Banyaknya video yang mesti tersedia dalam waktu relatif cepat, menuntut kecepatan kerja para pegawainya, termasuk staf di bagian pasca produksi yang salah satunya bertugas untuk melakukan pengeditan video. Pekerjaan pengeditan video ini dilakukan dua puluh empat jam dengan jumlah editor video yang tidak sedikit, sehingga dibutuhkan mekanisme penjadwalan editor video yang cepat, tepat, dan langsung dapat diketahui oleh editor video. Bisa jadi dalam satu minggu dibutuhkan lebih dari 500 jadwal editor video. Jika dilakukan secara manual, pengerjaan jadwal sebanyak itu tentulah tidak efisien.

Teknologi informasi telah banyak digunakan untuk membantu proses penjadwalan kerja. Di samping lebih cepat dan tepat, pemanfaatan teknologi informasi ini juga dapat mengurangi pemakaian kertas dan jadwal dapat diakses kapan pun dan di mana pun. Walau terdapat sisi negatif yang harus diwaspadai, menyangkut sisi keamanan, di mana jadwal tersebut bisa saja diakses oleh pihak yang tidak bertanggungjawab. Solusi sudah diberikan untuk masalah keamanan ini, yaitu antara lain dengan penambahan fitur seperti $\log$ in yang menggunakan user dan password (Montenegro, Pinto, \& Fuentes, 2017).

Banyak algoritma yang sudah dikembangkan untuk memecahkan masalah penjadwalan. Penjadwalan bekerja dengan banyak data sehingga memicu logika perhitungan yang rumit dalam perencanaan waktu dan penempatan data. Di Indonesia terdapat tiga jenis jadwal kerja, yaitu full time, part time dan shift time. Pada jadwal keja terdapat empat informasi yang umumnya selalu tersedia, yaitu jam, ruangan, jenis pekerjaan, dan karyawan sebagai aktornya. Media penempatan jadwal ini berupa selembar atau beberapa lembar kertas yang disatukan sehingga membentuk kotakkotak jadwal.

Penjadwalan memiliki dua pendekatan yaitu secara list dan secara kluster. Jadwal list dapat diartikan sebagai jadwal yang menyusun kepada nilai terbawah terhadap data yang dimasukkan, sedangkan jadwal secara kluster yakni penggabungan, pengelompokan serta pemesanan data yang sesuai dan masuk ke dalam suatu wilayah atau bagian (Wang \& Sinnen, 2018).

Optimalisasi pada penjadwalan mengaitkan beberapa metode pemecah masalah seperti metode tabu search atau metode optimasi pencarian yang berbasis pada local search dengan menggunakan algoritma heuristik (Shifting Bottleneck Procedure). Hasil yang diperoleh menggunakan algoritma ini belum cukup untuk penempatan jadwal karena dengan proses yang cepat akan membuat beberapa data mengalami kerusakan atau bug (Mellado,
Cubillos, \& Cabrera, 2016). Algoritma lainnya yang menerapkan penjadwalan seperti algoritma genetik yang mengambil beberapa contoh data yang terurai menjadi data yang kompleks namun memakan waktu lama serta memiliki tingkatan yang rumit dalam pengembangannya. Kekurangan algoritma genetik yaitu sistem acak yang dilakukan dalam mutasi dan persilangan yang mengakibatkan kromosom pertama terbaik akan hilang (Liu, Chen, \& Chou, 2014a)(Liu, Chen, \& Chou, 2014b)(Parera, Sukmana, \& Wardhani, 2016).

Metode baru untuk memecahkan penjadwalan telah dikembangkan dengan memperkenalkan algoritma ant colony sebagai pemecahan masalah. Dengan algoritma ant colony, tugas beban kerja dari proses pengumpulan jadwal akan lebih stabil dan cepat (Chen \& Zhang, 2013)(Nosheen, Bibi, \& Khan, 2013). Algoritma ant colony pernah dibandingkan dengan algoritma genetik dengan menerapkan pada penjadwalan tugas. Namun tingkat kecepatan pencarian global algoritma ant colony menghasilkan waktu terlambat dibanding algoritma genetik yang dikombinasikan pada node-node tertentu. Namun kecepatan tersebut tidak sebanding dengan hasil waktu yang efektif stabil (Liu et al, 2008). Begitu juga dengan penelitian yang dilakukan (Widyawati, 2018) yang menemukan bahwa algoritma ant colony menunjukkan penghematan waktu terhadap jadwal produksi yang digunakan pada kasus job shop scheduling problem.

Algoritma ant colony atau algoritma koloni semut merupakan algoritma yang meniru pada perilaku kebiasaan yang sering dilewati semut. Algoritma ant colony ini berkesinambungan dengan makhluk alam yang memiliki sifat alamiah yaitu sifat alami dari semut ketika mencari sarang atau tempat makan. Namun dalam pencarian jalur tercepat dan terstruktur, semut tidak membutuhkan penglihatan yang terang. Dalam dunia nyata semut yang mencari makan berkeliaran secara acak serta meninggalkan zat pada jejak mereka untuk dikenali atau diikuti oleh semut lainnya serta agar dapat mengenal jalan pulangnya. Zat tersebut disebut dengan feromon, semut yang mengeluarkan zat tersebut akan dideteksi oleh semut lainnya sehingga memiliki jalur yang bisa diikuti meskipun jalur itu pendek atau panjang. Akan tetapi, semut lainnya pun ikut menyebarkan feromon, sehingga akan lebih mudah bagi semut lain mendapatkan jalur terdekatnya.

Penelitian ini akan mengimplementasikan algoritma ant colony sebagai metode pengolahan data jadwal. Proses pengolahan data membutuhkan perangkat yang mendukung dari memory internal ataupun RAM (Random Access memory) pada smartphone. Tidak semua pengguna memiliki smartphone yang berkapasitas besar untuk memory internal dan RAMnya. Oleh sebab itu, pengolahan data pada jadwal shift staf editor video dilakukan diluar aplikasi yang digunakan pengguna. Pengolahan dilakukan dalam bagian back-end, dan 
untuk tampilan dilakukan di bagian front-end merupakan cara yang tepat untuk meringankan beban kerja dari smartphone pengguna. Teknik ini digunakan juga oleh (Haekal \& Eliyani, 2017) saat menghubungkan aplikasi Sikasir yang tersimpan di Cloud untuk terhubung ke android. Untuk penyimpanan jadwalnya menggunakan fitur basis data terbaru yakni firebase database di samping tetap menggunakan fitur database lokal. Firebase dari perusahaan Google dikembangkan untuk developer program dan dapat menampung data yang dihasilkan dari aplikasi pengolah. Firebase database tidak menggunakan perintah SQL (Structured Query Language) melainkan menggunakan JSON (JavaScript Object Notation) atau format pertukaran data yang mudah dibaca seperti pohon yang memiliki batang, akar dan daun. Database ini hanya untuk penyimpanan data publik dalam cloud service (Li et al, 2018).

\section{METODOLOGI PENELITIAN}

Penelitian ini termasuk dalam penelitian kuantitatif. Dilakukan wawancara untuk menentukan data masukan dan informasi yang diharapkan.

\section{a. Algoritma}

Algoritma yang digunakan pada penelitian ini yaitu algoritma ant colony dengan jumlah iterasi sesuai dengan permintaan dari bakal pengguna aplikasi. Pengguna aplikasi dapat mengedit data yang diketikkan.

Algoritma Ant Colony disajikan pada Gambar 1 dibawah ini.

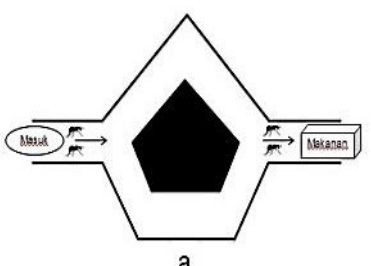

a

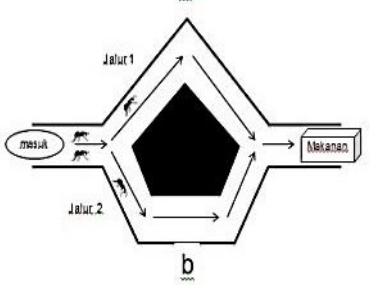

Gambar 1. Langkah Algoritma Ant Colony (Alfrerio Risvan Effriandi \& Artha Zenda, 2010)

Gambar 1 mengilustrasikan tahapan di mana semut pada akhirnya mampu menemukan jejak tercepat dan kemudian diikuti oleh semut lainnya:

a. Langkah pertama semut berjalan mengelilingi rute/jalur.

b. Ketika semut-semut menemukan jalur yang berbeda contohnya seperti pada simpang, mereka akan berpisah dengan melewati kedua jalur tersebut. c. Semut akan berpisah dengan melewati jalan atas dan jalan bawah, ketika mereka berjalan, mereka melakukan peninggalan jejak dengan zat feromon. Lalu jejak feromon tersebut diikuti oleh semut-semut lainnya, sehingga semut di belakangnya yakni semut jalur bagian atas dan bawah akan terlihat siapa yang datang terlebih dahulu dengan jalur tercepat.

d. Dengan mengikuti jejak tercepat menuju titik seberang, maka semut yang sudah sampai di depan akan memberitahu semut yang di belakang untuk mengikuti jejak tercepat dan semut lain akan mengikutinya.

Pada penelitian ini, pasukan semutnya adalah staf editor video. Pada satu ruangan hanya dapat ditempati oleh tiga editor video, dan satu ruangan tersebut digunakan untuk tiga shift kerja, yaitu shift jadwal kerja pukul: (a) 00.00-07.59; (b) 08.00-15.59; dan (c) 16.00-23.59. Logikanya disajikan pada Gambar 2.

a) Shift 00.00-07.59 wib

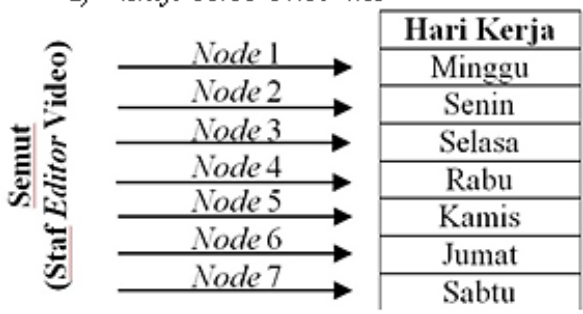

b) Shift 08.00-15.59 wib

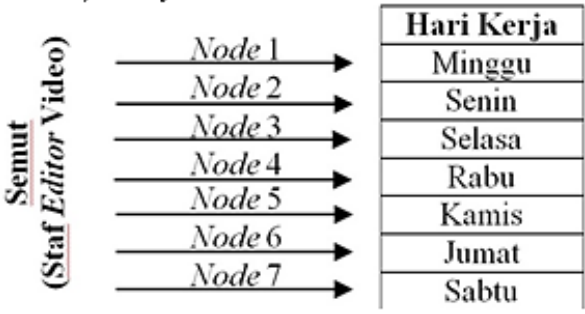

c) Shift 16.00-23.59 wib

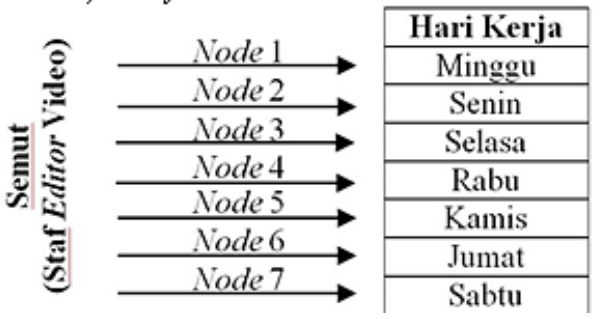

Gambar 2. Logika Ant Colony untuk editor video (Alfrerio Risvan Effriandi \& Artha Zenda, 2010)

Pada penerapan algoritma ant colony, nodenode tersebut atau jalur tersebut diimplementasikan sebagai susunan array ke dalam tabel hari. Untuk menyusun serta mengolah data yang dimasukkan dari hasil yang diketikkan oleh pengolah jadwal, implementasi algoritma ant colony pada penelitian ini adalah sebagai berikut: 
1. Langkah awal identifikasi jarak yang digunakan untuk penentuan jarak yakni dari node 1 ke node 2 (langkah 1 dan 2 untuk jalurasemut).

2. Langkah selanjutnya adalah inisialisasi parameter awal bagi feromon pada waktu ke $-t$. Pada implementasinya menggunakan index array dengan menghubungkan semua hari dan editor yang diketikkan yang membentuk sebuah list.

3. Menentukan jumlah semut dengan meletakkan $m$ semut pada $n$ nodes. Semut pada data yaitu data editor video yang akan diletakkan pada hari sesuai urutan hari kerja lima hari dalam satu minggu.

4. Kemudian dilakukan iterasi pada setiap langkah agar tidak ada jadwal yang bentrok dan/atau tidak terdapat ruangan yang kosong. Iterasi dilakukan sampai seluruh editor video mendapatkan shift kerja pada hari tersebut untuk periode selama satu minggu.

5. Langkah selanjutnya adalah memutakhirkan feromon untuk periode berikutnya. Feromon berupa jejak untuk menemukan hari kerja dan periode kerja.

6. Langkah terakhir adalah mencetak hasil atau jadwal yang sudah dibentuk.

\section{b. Database Firebase}

Firebase dalam penelitian ini digunakan sebagai database cadangan untuk menampilkan hasil jadi dari pengembangan jadwal shift editor video. Firebase berfungsi jika database lokal dalam keadaan tidak terkoneksi atau terdapat gangguan. Jika data sudah selesai diolah oleh Koordinator editor video selaku pengolah jadwal, maka database utama tidak lagi dibutuhkan.

Firebase memiliki sistem yang stabil sebagai penyimpan dan penyalur database. Untuk mengirimkan data jadwal yang sudah diolah maupun melihat hasil jadwal dibutuhkan koneksi internet. Permintaan serta pengiriman data ke Firebase bersifat realtime sehingga dapat langsung dikirim dari sistem yang mengolah data jadwal dan diterima oleh sistem yang menampilkan data jadwal tersebut. Dengan demikian, sangat membantu dalam proses kejar tayang yang menjadi kebutuhan stasiun televisi.

Penelitian ini masih menggunakan Firebase yang gratis sehingga hanya mendapatkan kuota tidak melebihi 1 gigabyte untuk setiap proyek.

\section{c. Metode pengembangan perangkat lunak}

Pengembangan perangkat lunak pada penelitian ini menggunakan Metode SDLC (Systems Development Life Cycle) atau Metode waterfall seperti diilustrasikan pada Gambar 3. Dimulai dari (1) analisa kebutuhan sistem dengan melakukan proses wawancara di salah satu Stasiun Televisi Nasional yaitu Trans 7, kemudian dilakukan (2) desain aplikasi yang dibuat secara rinci menggunakan UML (Unified Modeling Language), kemudian (3) penulisan kode program yang berkaitan dengan algoritma ant colony dan dilengkapi dengan beberapa fitur lanjutan seperti log in menggunakan Bahasa Java IntelliJ IDEA versi trial dan android studio versi tidak berbayar, (4) pengujian program, merupakan proses verifikasi antara pengembang dan pengguna aplikasi yaitu Koordinator editor sebagai pembuat jadwal dan editor video, dan langkah terakhir yaitu (5) pemeliharaan sistem yang dilakukan pada saat bersamaan dengan penulisan kode program.

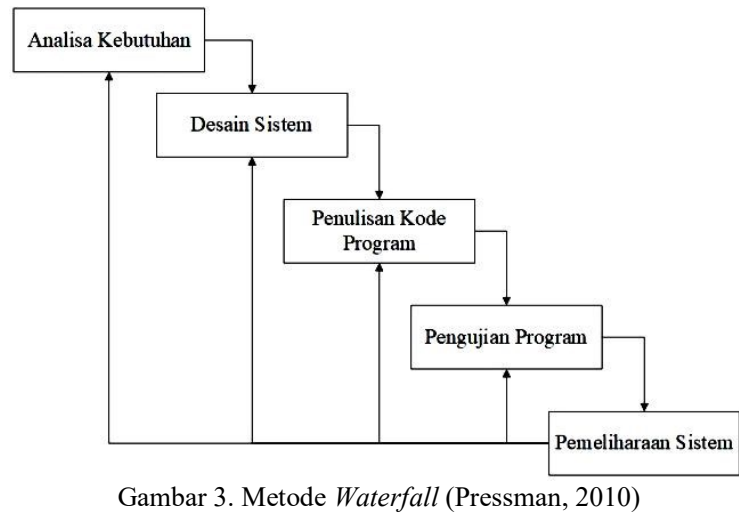

\section{HASIL DAN PEMBAHASAN}

\subsection{Analisa kebutuhan}

Setelah dilakukan analisis data yang diperoleh dari wawancara kepada pihak terkait di Stasiun Televisi Nasional Trans7, kebutuhan sistem untuk aplikasi penjadwalan editor video ini adalah:

1. Koordinator sebagai pengolah data melakukan:

$>$ Buka aplikasi jadwal

$>$ Log in sebagai Koordinator

$>$ Manajemen data ruangan

$>$ Manajemen data editor video

$>$ Buat jadwal

$>$ Lihat jadwal

2. Editor video sebagai pengguna aplikasi melakukan:

$>$ Buka aplikasi jadwal

$>$ Lihat jadwal

\subsection{Desain Sistem}

\section{a. Pemodelan proses}

Perancangan perangkat lunak jadwal shift editor video menggunakan UML yang dibagi menjadi lima model, yaitu Proses Bisnis, Diagram Konteks, Diagram Alir Data, Diagram Aktivitas, dan Diagram Urutan (sequence).

1. Proses Bisnis

Proses bisnis aplikasi adalah:

a) Aplikasi terbuka maka muncul halaman untuk $\log$ in dan lihat jadwal. 
b) Koordinator melakukan pengetikan pada halaman log in untuk memulai memasukkan data.

c) Sistem menyediakan halaman untuk memasukkan data jadwal dengan tanda ' + ' untuk menambah seperti manajemen ruangan dan manajemen editor, untuk edit data dapat menekan list datanya.

d) Sistem merekam data masukan, namun jika ada salah ketik atau belum input maka akan muncul notifikasi data belum lengkap.

e) Sistem mengirimkan data yang sudah valid ke database utama.

f) Koordinator menekan tombol halaman lihat jadwal, lalu menekan tanda '+' untuk membuat jadwal, selanjutnya Koordinator mengisi field yang berada pada form jadwal dan menekan tombol create untuk mengolah jadwal. Jadwal akan terlihat dalam bentuk tabel.

Diagram use case yang menggambarkan proses bisnis tersebut disajikan pada Gambar 4.

\section{Diagram konteks}

Jadwal shift editor video ini terdiri dari dua sistem yaitu sistem Koordinator dan sistem jadwal shift seperti disajikan pada Gambar 5. Sistem Koordinator merupakan aktor dalam pengolahan jadwal. Isi atau record dari field-field yang sudah dimasukkan oleh Koordinator akan disimpan pada sistem jadwal shift. Sistem jadwal shift akan mengirimkan hasil olahan jadwal kembali ke Koordinator.

\section{Diagram Alir Data}

Gambar 6 menampilkan diagram alir data. Koordinator selaku pengolah jadwal melakukan $\log$ in untuk melanjutkan edit data editor, ruangan dan jadwal. Setelah data berhasil dimasukkan maka sistem tampilan data akan menyimpan data jadwal dan memberikan hasil berupa output ke halaman lihat jadwal yang dapat dilihat oleh Koordinator maupun editor video.

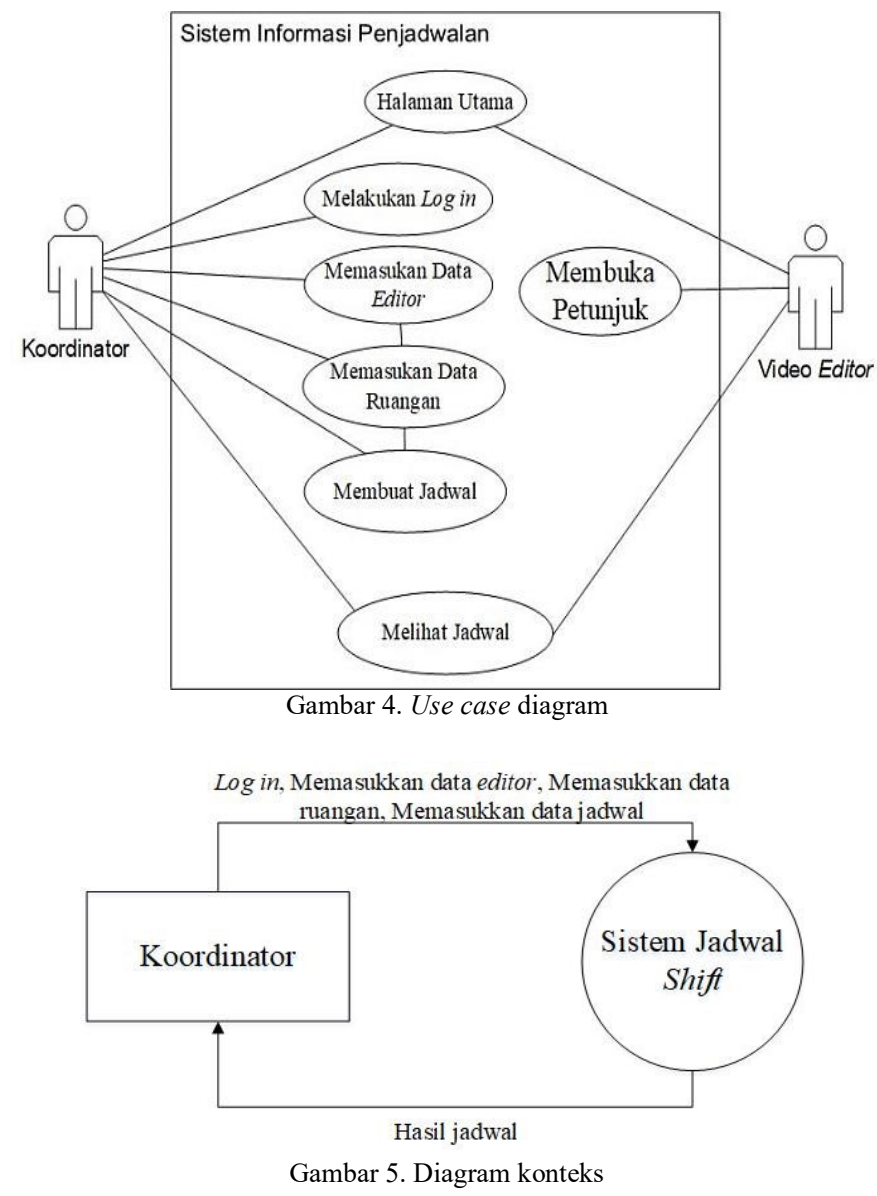




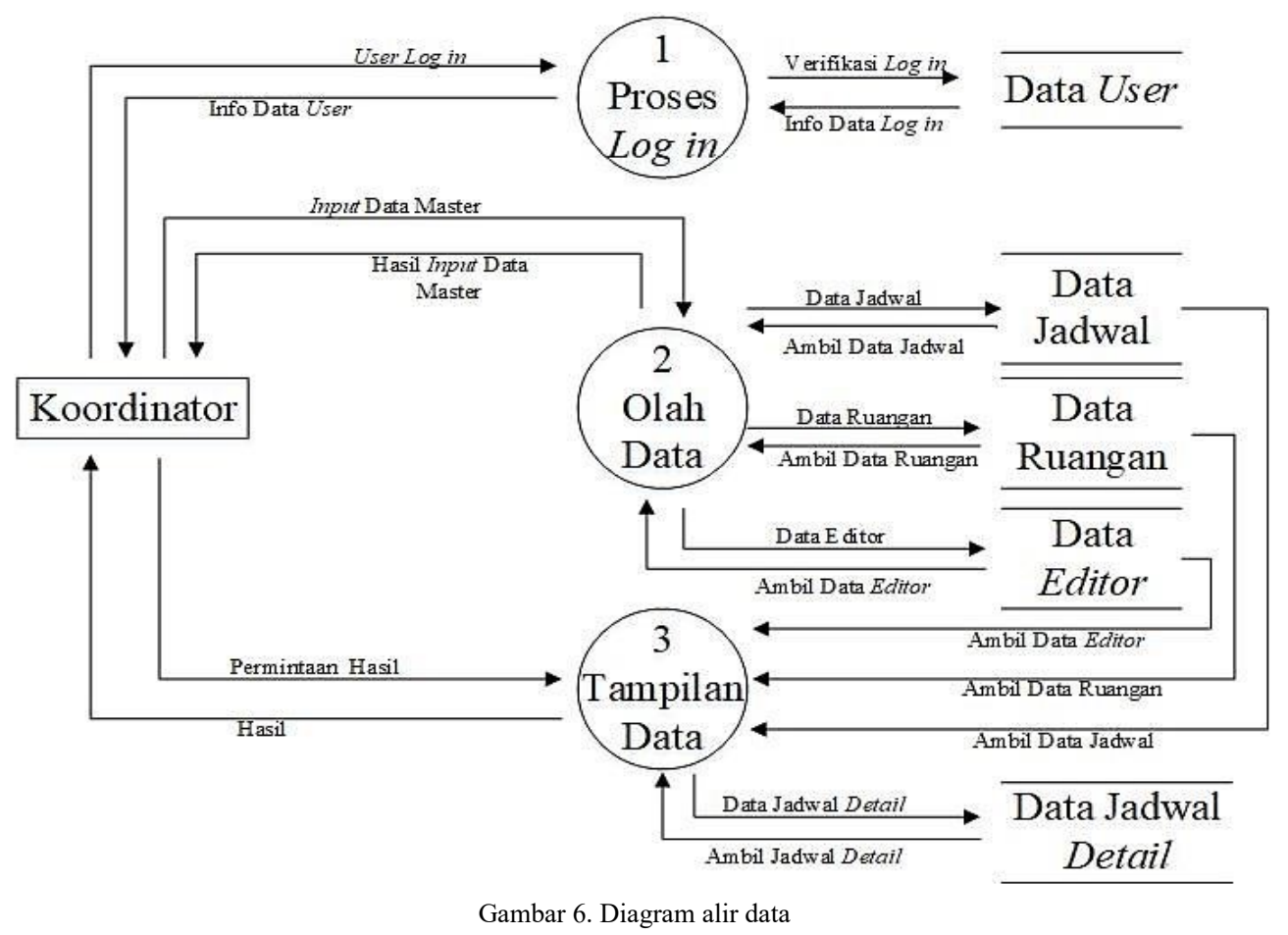

\section{Diagram Aktivitas}

Aktivitas tambah data editor dilakukan setelah log in sebagai Koordinator dan tampilan akan muncul jika database utama terhubung dengan aplikasi. Koordinator menekan menu home pada kiri atas menu navigasi dan menekan tombol '+' pada kanan bawah agar sistem menampilkan form tambah editor. Koordinator dapat mengisi form data editor tersebut yang terdiri dari nomor induk karyawan, nama dan nomor telepon. Dengan menekan tombol add, sistem menyimpan data editor tersebut. Kemudian dilanjutkan dengan aktivitas input data ruangan.

Pada aktivitas mengisi data ruangan, Koordinator melakukan penekanan tombol menu home kembali, dan dapat menekan tombol manajemen ruangan. Sistem menampilkan form input ruangan untuk Koordinator mengisi nama ruangan. Dengan menekan tombol add, sistem langsung menyimpan data ruangan.

Langkah aktivitas selanjutnya adalah pengolahan jadwal. Untuk aktivitas ini, Koordinator menekan tombol lihat jadwal agar form olah jadwal tersedia. Setelah itu, dengan menekan tombol '+' pada kanan bawah, sistem akan menampilkan form buat jadwal yang terdiri dari daftar ruangan, periode, dan pilihan untuk editor dapat masuk di hari yang sama. Setelah Koordinator melakukan pengisian data, maka hasil berupa jadwal shift akan terlihat pada menu navigasi lihat jadwal. Diagram aktivitas olah jadwal ini disajikan pada Gambar 7.

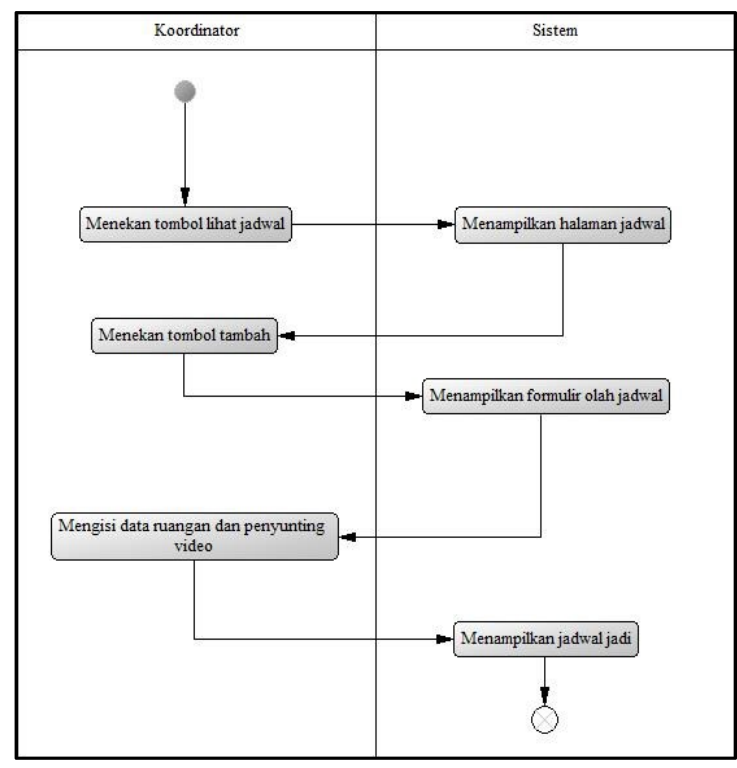

Gambar 7. Aktivitas olah jadwal shift editor video

\section{Diagram Urutan}

Merujuk pada diagram aktivitas, terdapat dua data yang dimasukkan ke sistem yaitu data editor dan data ruangan yang berakhir pada proses penyimpan data. Proses olah jadwal dilakukan dengan aktor Koordinator dan beberapa database seperti jadwal, role, dan jadwal detail. Diagram urutan proses olah jadwal disajikan pada Gambar 8, namun pada Gambar 8, database hanya diwakilkan oleh data jadwal. 


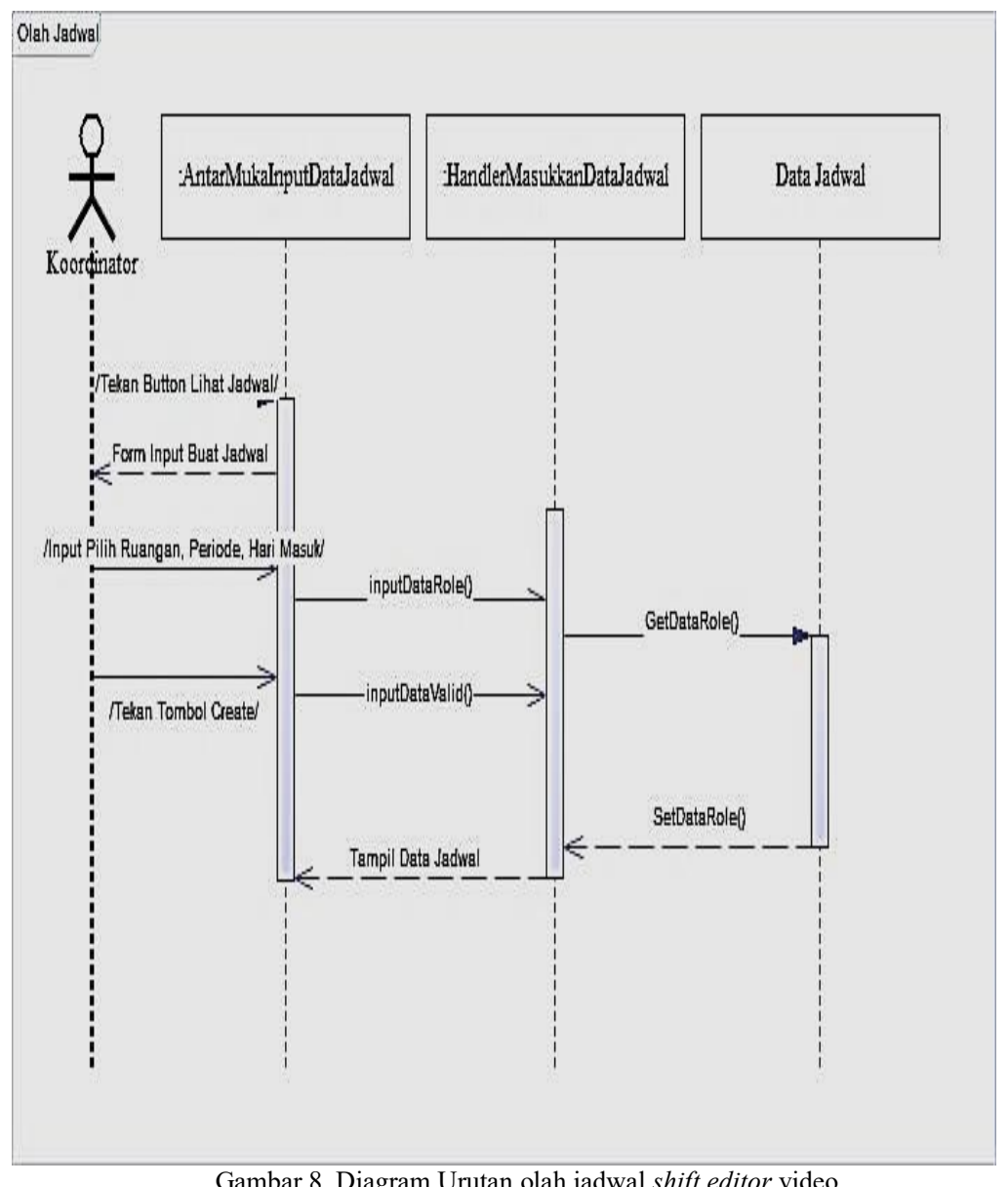

\section{b. Pemodelan Data}

ERD (Entity Relationship Diagram) pada database MySQL untuk penelitian ini disajikan pada Gambar 9.

Terdapat enam tabel database, yaitu:

Tabel Ruangan memiliki:

- id_Ruangan (Primary key)

- nama Ruangan

Tabel Editor memiliki:

- id_Editor (Primary Key)

- nama Editor

- nomer Telepon

Tabel Role memiliki fungsi untuk menentukan semua editor masuk di hari yang sama:

- id Role (Primary Key)

- all editor in

- id_Ruangān (Foreign Key)

Tabel Jadwal memiliki:

- id Jadwal (Primary Key)

- id_Ruangan (Foreign Key)

- create_Date

- year

- week in year

- month
- period

Tabel Jadwal Detail merupakan tabel transaksi:

- id jadwal detail (Primary Key)

- $\quad$ id_editor (Foreign Key)

- id_ruangan (Foreign Key)

- $\quad$ sunday

- monday

- tuesday

- thursday

- wednesday

- friday

- saturday

- $\quad$ shift_number

- range hours

Tabel User Log in memiliki:

- id_user (Primary Key)

- nomer_telepon (Primary Key)

- nama

- password

- register_date

- $\quad$ status

Tampilan data dalam database utama $M y S Q L$ yang menyimpan tabel-tabel tersebut disajikan pada Gambar 10 dan tampilan database Firebase yang menjadi database cadangan untuk menampilkan hasil jadwal disajikan pada Gambar 11. 


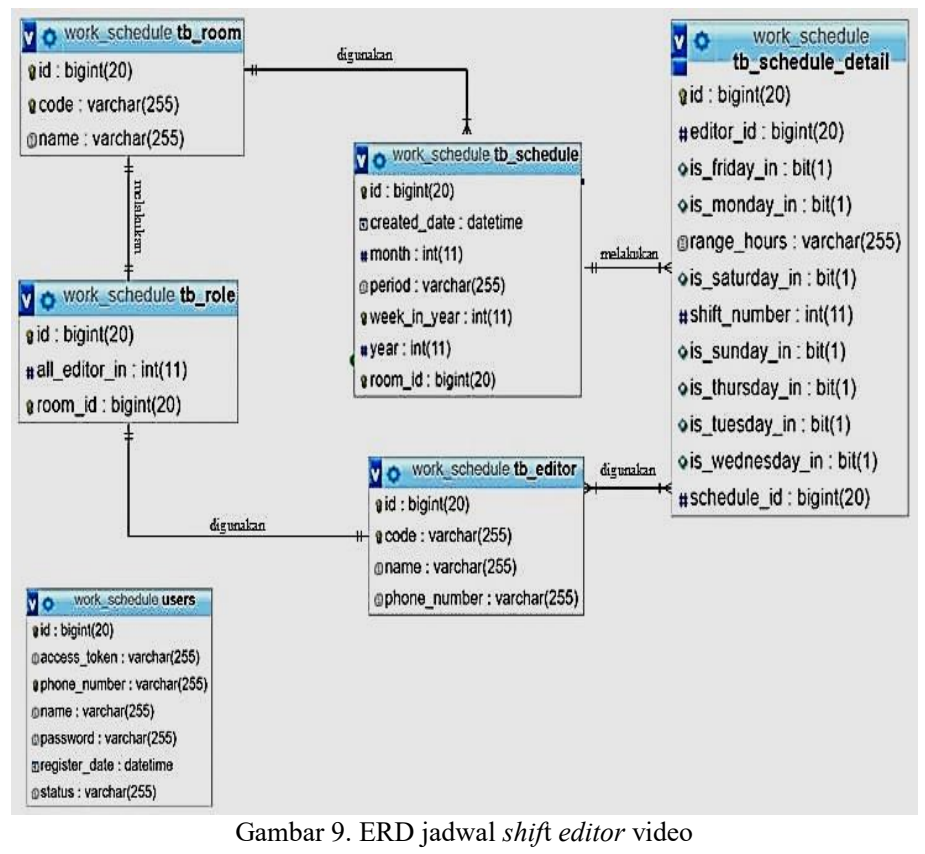

\begin{tabular}{|c|c|c|c|c|c|c|}
\hline & Table & Action & Rows (9) Type & Collation & Size & Overhead \\
\hline 0 & tb_editor & 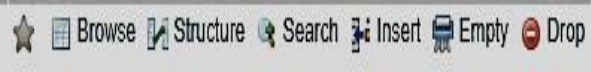 & 81 InnoDB & latin1_swedish_ci & $32 \mathrm{KiB}$ & 8 \\
\hline 0 & tb_role & 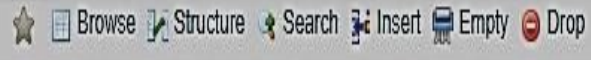 & $28 \mathrm{InnODB}$ & latin1_swedish_ci & $32 \mathrm{KiB}$ & \\
\hline 0 & th_room & 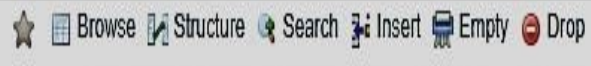 & ${ }^{28} \mathrm{InnODB}$ & latin1_swedish_ci & $32 \mathrm{KiB}$ & \\
\hline 0 & tb_schedule & 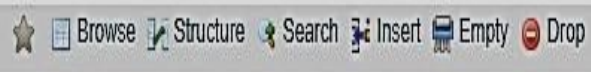 & ${ }^{29} \mathrm{InnODB}$ & latin1_swedish_ci & $32 \mathrm{KiB}$ & \\
\hline 0 & tb_schedule_detail & 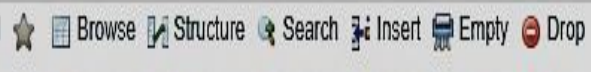 & ${ }^{68} \mathrm{InnODB}$ & Iatin1_swedish_ci & $32 \mathrm{KiB}$ & \\
\hline 0 & users & 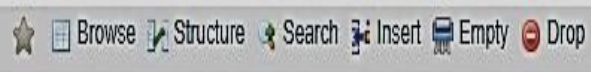 & 2 InnODB & latin1_swedish_ci & $16 \mathrm{KiB}$ & \\
\hline & 6 tables & Sum & $2191 \mathrm{lnnoDE}$ & 3 latin1_swedish_ci & 176 KiB & $O B$ \\
\hline
\end{tabular}

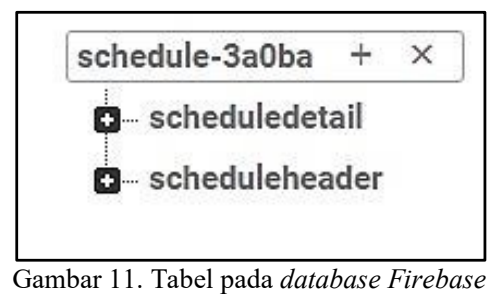

Database utama merupakan database MySQL yang menyimpan berbagai tabel dan perintah SQL untuk mengolah jadwal shift editor video secara keseluruhan. Database Firebase hanya menyimpan dua root atau yang disebut dengan JSON (Java Script Object Notation). File yang disimpan dalam database pada pengembangan jadwal shift staf editor video memiliki 2 file yaitu jadwal detail dan jadwal header. Pada jadwal header berisi dari format atau tempat yang menyimpan hasil jadi olah data, sedangkan jadwal detail berisi data-data yang akan disimpan ke dalam jadwal header. Kedua susunan file tersebut akan saling berhubungan dan tidak bentrok.
Data yang digunakan dalam pengembangan jadwal shift staf editor video menggunakan data yang diambil dari contoh data yang sudah ada dari perusahaan, dalam bentuk bahasa $M y S Q L$ disajikan pada Gambar 12. Data editor video yang dimasukkan sebanyak yang terdapat dalam sistem asli, yaitu 81 editor dengan dilengkapi data nomor induk karyawan, nama dan nomor telepon. Data ruangan yang dimasukkan sebanyak 26 ruangan seperti pada sistem nyata yang menjadi obyek pengamatan.

\section{a. Pengujian dan Hasil}

Beberapa tampilan aplikasi ini disajikan pada Gambar 13 sampai Gambar 18. Gambar 13 menampilkan halaman utama aplikasi, di mana pada smartphone yang memiliki operasi sistem android, tanpa melakukan perpindahan atau menekan tombol, jadwal akan muncul pada halaman utama saat membuka aplikasi jadwal shift editor video.

Gambar 14 menampilkan form manajemen ruangan untuk ditempati para editor video dan hanya 
dituliskan dalam sebuah text, contoh: Booth A, Booth B dan seterusnya.

Tampilan hasil input ruangan disajikan pada Gambar 15.

Gambar 16 menampilkan halaman manajemen editor di mana Koordinator dapat memasukkan nomor induk karyawan, nama dan nomor telepon editor video. Hasil input dari halaman tersebut disajikan pada Gambar 17.
Tampilan halaman untuk mengolah jadwal disajikan pada Gambar 18., terdiri dari data ruangan yang sudah dimasukkan sebelumnya, periode jadwal yang terdiri dari bulan dan tahun, serta pertanyaan kepada Koordinator yang diperlukan jika ada satu hari dalam seminggu editor dari semua shift harus masuk dan diperlukan jika ada rapat koordinasi kerja.

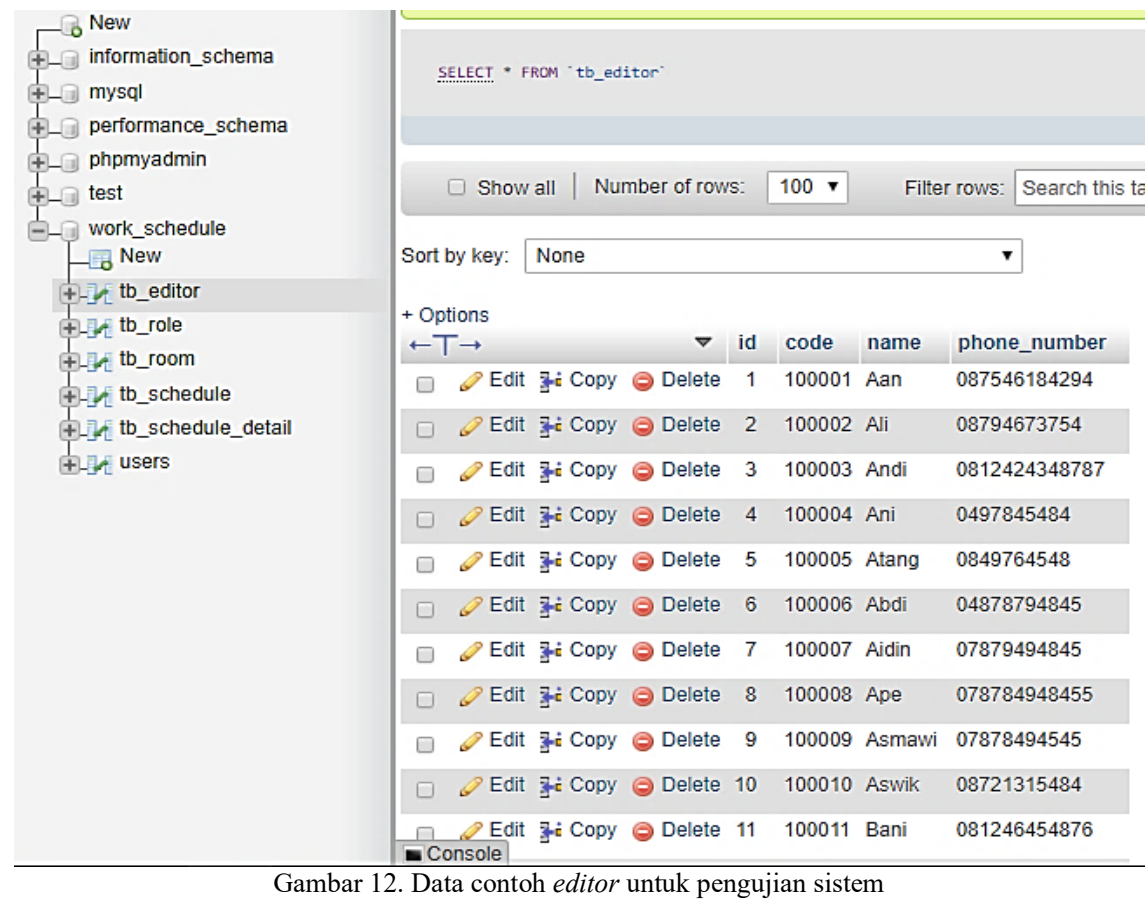

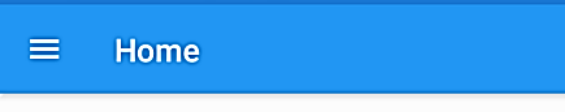

Nama Ruangan : A

$\begin{array}{ll}\text { Tanggal } & : 04 / 11 / 2018- \\ 10 / 11 / 2018\end{array}$

Nama Ruangan : A

Tanggal $\quad: 11 / 11 / 2018$ -

$17 / 11 / 2018$

Nama Ruangan : A

Tanggal : :18/11/2018-

$24 / 11 / 2018$

Nama Ruangan : A

Tanggal :25/11/2018 -

$01 / 12 / 2018$

Nama Ruangan : B

Tanggal : :04/11/2018 -

$10 / 11 / 2018$

Gambar 13. Tampilan halaman utama

\section{$\leftarrow \quad$ Manajemen Room}

Name

\section{ADD}

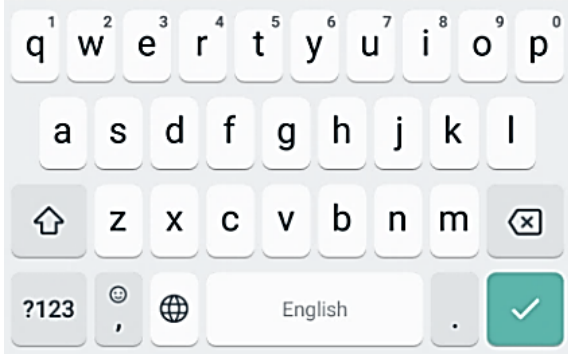

Gambar 14. Tampilan menu manajemen ruangan 


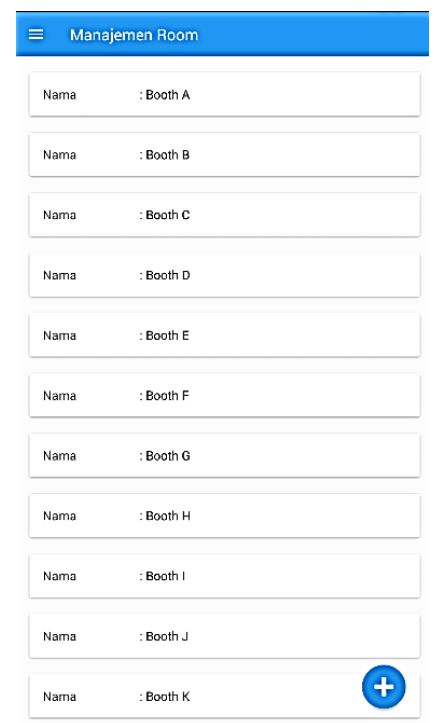

Gambar 15. Tampilan hasil input data ruangan

$$
\leftarrow \text { Manajemen Editor }
$$
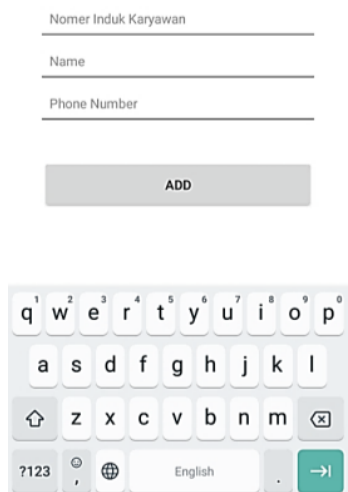

Gambar 16. Tampilan menu manajemen editor

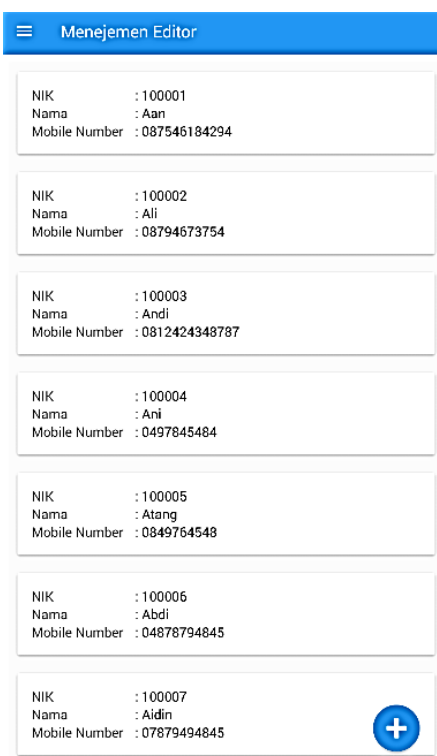

Gambar 17. Tampilan hasil input data editor

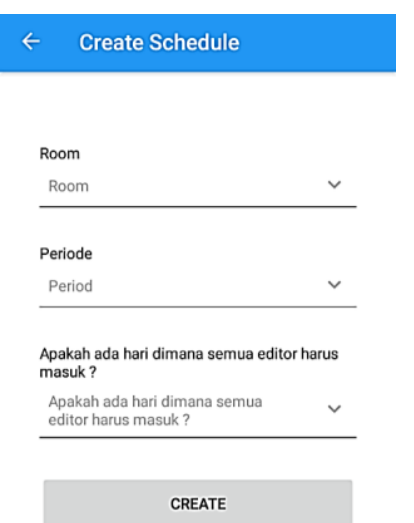

Gambar 18. Tampilan halaman olah jadwal

\subsection{Pengujian sistem}

Pengujian aplikasi menggunakan perangkat sebagai berikut:

1. Sistem operasi android minimal API (Application Programming Interface) versi 19 atau versi sistem operasi android 4.4 (KitKat).

2. Memiliki memory internal minimal 1 gigabyte.

3. Memiliki kapasitas memory eksternal minimal 1 gigabyte.

4. Smartphone yang menggunakan aplikasi penjadwalan harus memiliki internet servis yang berguna untuk mengakses jadwal pada Firebase.

Pengujian algoritma ant colony untuk penjadwalan kerja editor video dilakukan untuk 26 ruangan, 81 editor, periode satu pekan untuk tiga shift per hari. Jadwal yang dihasilkan disajikan pada Gambar 19.

Menggunakan aplikasi tersebut dihasilkan 390 jadwal dengan waktu olah data sekitar 1 sampai 2 menit.

Jadwal tersebut dapat dilihat pada smartphone dengan tampilan seperti pada Gambar 20 untuk satu ruangan (Ruangan A).

Selanjutnya dilakukan pengujian black box dan pengujian penggunaan. Pengujian black box dilakukan terhadap beberapa fitur untuk menguji fungsional sistem, integrasi, dan penerimaan yang dikembalikan pada sistem dengan mencari kesalahan pada interface perangkat lunak. Pengujian black box berfokus kepada tombol-tombol keseluruhan pada aplikasi jadwal shift editor video yang hasilnya disajikan pada Tabel 1. 


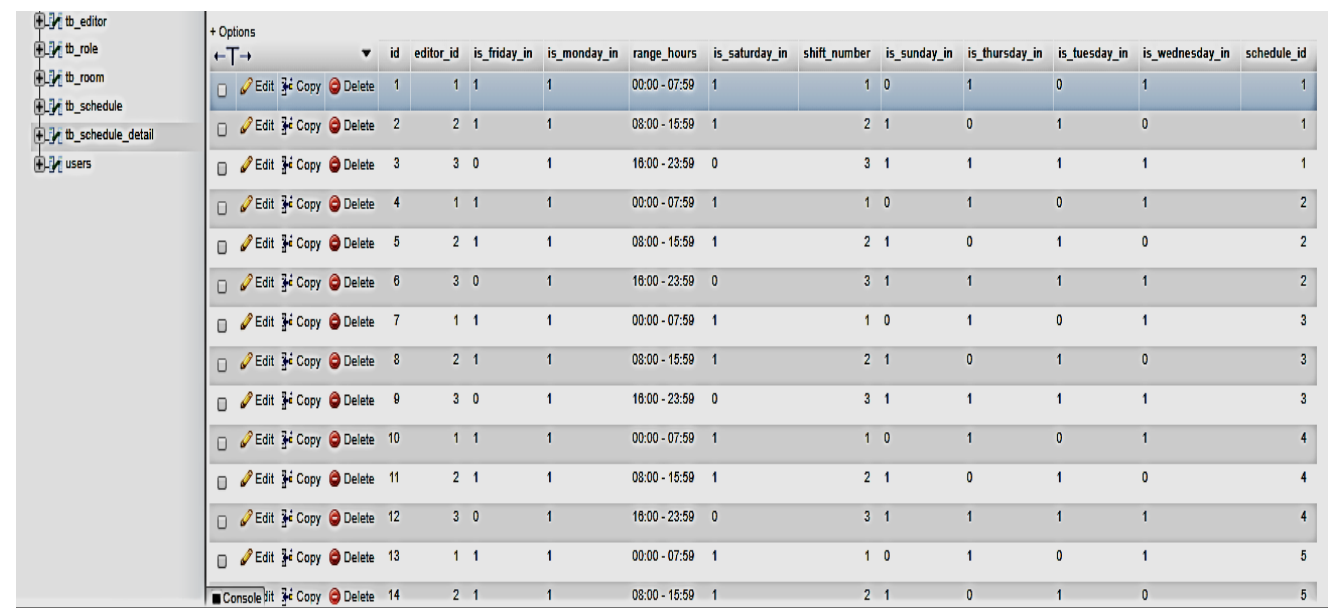

Gambar 19. Pengujian sistem olah jadwal $(M y S Q L)$

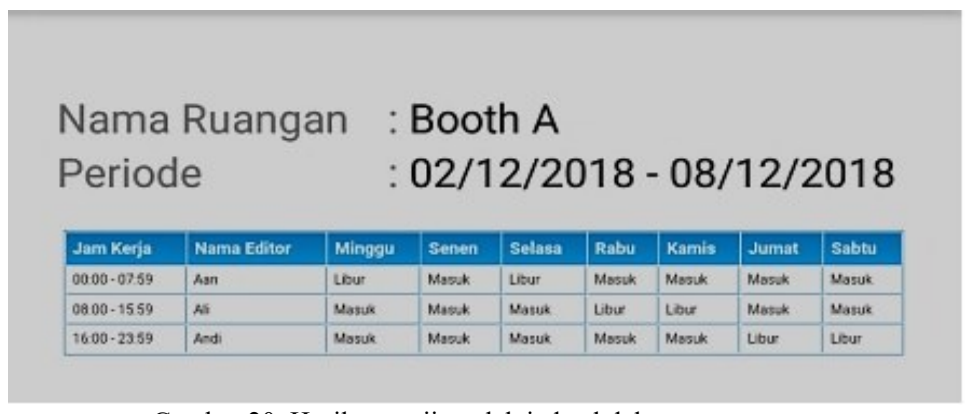

Gambar 20. Hasil pengujian olah jadwal dalam satu ruangan

Tabel 1. Penguiian Interface dengan Teknik Black Box

\begin{tabular}{|c|c|c|c|}
\hline No & Skenario & Kondisi & Kesimpulan \\
\hline 1 & $\begin{array}{c}\text { Halaman } \\
\text { Utama }\end{array}$ & $\begin{array}{c}\text { Ketika membuka } \\
\text { aplikasi langsung } \\
\text { ke halaman utama } \\
\text { aplikasi. }\end{array}$ & Valid \\
\hline 2 & $\begin{array}{l}\log \text { in } \\
\text { Koordinator }\end{array}$ & $\begin{array}{l}\text { Koordinator sebagai } \\
\text { administrator } \\
\text { pengolah jadwal } \\
\text { dapat masuk } \\
\text { sebagai pengolah } \\
\text { data. }\end{array}$ & Valid \\
\hline 3 & Lihat Jadwal & $\begin{array}{l}\text { Menampilkan } \\
\text { jadwal yang telah } \\
\text { selesai diolah. }\end{array}$ & Valid \\
\hline 4 & $\begin{array}{l}\text { Manajemen } \\
\text { Ruangan }\end{array}$ & $\begin{array}{l}\text { Halaman yang } \\
\text { memandu } \\
\text { koordinator untuk } \\
\text { mengolah data } \\
\text { ruangan seperti } \\
\text { tambah, edit dan } \\
\text { hapus data ruangan. }\end{array}$ & Valid \\
\hline 5 & $\begin{array}{l}\text { Manajemen } \\
\text { Editor }\end{array}$ & $\begin{array}{l}\text { Halaman yang } \\
\text { memandu } \\
\text { koordinator untuk } \\
\text { mengolah data } \\
\text { editor video seperti } \\
\text { tambah, edit dan } \\
\text { hapus data editor. }\end{array}$ & Valid \\
\hline 6 & Petunjuk & $\begin{array}{l}\text { Menampilkan } \\
\text { petunjuk atau tata } \\
\text { cara penggunaan } \\
\text { aplikasi untuk } \\
\text { melihat jadwal. }\end{array}$ & Valid \\
\hline 7 & Keluar aplikasi & $\begin{array}{c}\text { Menunjukkan } \\
\text { aplikasi telah } \\
\text { keluar. }\end{array}$ & Valid \\
\hline
\end{tabular}

Pengujian penggunaan langsung dilakukan pada pengguna aplikasi jadwal shift editor video yaitu aktor editor video dan koordinator editor. Tujuan dari pengujian ini adalah untuk mengetahui seberapa layak aplikasi jadwal shift ini dalam membantu proses menentukan jadwal editor video yang berkaitan dengan proses cepat tayang dalam dunia pertelevisian. Diharapkan tentu saja, aplikasi ini dapat membantu mempermudah pekerjaan editor video dan koordinator editor.

Pengujian dilakukan dengan memberikan kuesioner dan melakukan uji coba terhadap aplikasi yang telah dibangun. Untuk editor video diberikan empat pertanyaan, yaitu : (1) kemudahan mengakses aplikasi, (2) kemudahaan mengakses halaman petunjuk, (3) kemudahan melihat jadwal pada aplikasi, dan (4) kemudahan keluar dari aplikasi. Pengujian dilakukan terhadap 21 editor video. Hasil pengujian penggunaan oleh editor video disajikan pada Tabel 2. Rata-rata tingkat kemudahan dalam menggunakan aplikasi tersebut menurut para editor video sekitar $80 \%$ dalam rentang 0 hingga $100 \%$. Kelemahan utamanya adalah belum terdapatnya halaman petunjuk penggunaan aplikasi yang menurut mereka tetap diperlukan. Saran-saran yang diberikan untuk pengembangan aplikasi disajikan pada juga pada Tabel 2. 
Hasil pengujian penggunaan oleh Koordinator editor disajikan pada Tabel 3. Pengujian dilakukan terhadap satu-satunya Koordinator editor video yang menjabat di Stasiun Televisi Nasional Trans7. Pertanyaan diberikan melalui kuesioner yang diisikan setelah Koordinator menggunakan aplikasi tersebut.

Pertanyaan tersebut terdiri dari : (1) kemudahan mengakses halaman utama aplikasi, (2) kemudahaan $\log$ in, (3) kemudahan memasukkan data editor, (4) kemudahan memasukkan data ruangan, (5) kemudahan memasukkan jumlah editor untuk melihat hasil jadwal, (6) kemudahan untuk mengedit data, (7) tingkat kecepatan menentukan jadwal, (8) kelebihan aplikasi ini dibanding proses penjadwalan secara manual, dan (9) kemudahan keluar dari aplikasi. Kepuasan Koordinator editor dalam penggunaan aplikasi mencapai $90 \%$ dengan saransaran perbaikan disajikan pada Tabel 3.

\section{KESIMPULAN}

Kesimpulan yang dapat diambil dari pengembangan jadwal shift editor video yang dibangun menggunakan algoritma Ant Colony dan database Firebase antara lain:

1. Implementasi algoritma Ant Colony yang didukung oleh database Firebase, dapat menghasilkan jadwal dengan tepat dan cepat.

2. Tingkat kepuasan pengguna yaitu para editor video dan Koordinator editor relatif tinggi sekitar $80 \%$ untuk editor video dan 90\% untuk Koordinator editor.

3. Firebase mempermudah hasil aplikasi untuk secara realtime yang dilihat melalui smartphone android.

\begin{tabular}{|c|c|c|c|}
\hline No & Kuesioner & Hasil & Saran \\
\hline 1 & $\begin{array}{c}\text { Berapa } \\
\text { persentase } \\
\text { kemudahan } \\
\text { mengakses } \\
\text { aplikasi. }\end{array}$ & 87 & $\begin{array}{l}\text { Sudah cukup } \\
\text { mudah } \\
\text { dalam } \\
\text { penggunaan. }\end{array}$ \\
\hline 2 & $\begin{array}{c}\text { Berapa } \\
\text { persentase } \\
\text { kemudahaan } \\
\text { mengakses } \\
\text { halaman } \\
\text { petunjuk. }\end{array}$ & 52 & $\begin{array}{c}\text { Info } \\
\text { petunjuk } \\
\text { penggunaan } \\
\text { aplikasi } \\
\text { belum ada. }\end{array}$ \\
\hline 3 & $\begin{array}{l}\text { Berapa } \\
\text { persentase } \\
\text { kemudahan } \\
\text { untuk melihat } \\
\text { jadwal pada } \\
\text { aplikasi. }\end{array}$ & 89 & $\begin{array}{l}\text { Sudah cukup } \\
\text { mudah } \\
\text { karena } \\
\text { tampil pada } \\
\text { awal aplikasi } \\
\text { dibuka. }\end{array}$ \\
\hline 4 & $\begin{array}{c}\text { Berapa } \\
\text { persentase } \\
\text { kemudahan } \\
\text { untuk keluar } \\
\text { dari aplikasi. }\end{array}$ & 86 & $\begin{array}{l}\text { Tidak ada } \\
\text { menu keluar }\end{array}$ \\
\hline \multicolumn{2}{|c|}{ Persentase } & \multicolumn{2}{|c|}{$\frac{314}{4}=79 \%$} \\
\hline
\end{tabular}

Tabel 3. Pengujian penggunaan aplikasi untuk Koordinator

\begin{tabular}{|c|c|c|c|}
\hline No & Kuesioner & Hasil & Saran \\
\hline 1 & $\begin{array}{l}\text { Berapa persentase } \\
\text { kemudahan } \\
\text { mengakses halaman } \\
\text { utama aplikasi. }\end{array}$ & 90 & $\begin{array}{l}\text { Sudah baik } \\
\text { karena aplikasi } \\
\text { ringan. }\end{array}$ \\
\hline 2 & $\begin{array}{l}\text { Berapa persentase } \\
\text { kemudahaan } \log \text { in } \\
\text { Koordinator. }\end{array}$ & 90 & $\begin{array}{c}\text { Sudah cukup } \\
\text { baik dengan log } \\
\text { in nomor } \\
\text { handphone dan } \\
\text { password sangat } \\
\text { unik. }\end{array}$ \\
\hline 3 & $\begin{array}{c}\text { Berapa persentase } \\
\text { kemudahan untuk } \\
\text { memasukkan data } \\
\text { editor. }\end{array}$ & 85 & $\begin{array}{l}\text { Perlu diperjelas } \\
\text { pada bagian isi } \\
\text { kolom. }\end{array}$ \\
\hline 4 & $\begin{array}{c}\text { Berapa persentase } \\
\text { kemudahan untuk } \\
\text { memasukkan data } \\
\text { ruangan. }\end{array}$ & 90 & $\begin{array}{l}\text { Sudah cukup } \\
\text { mudah } \\
\text { digunakan. }\end{array}$ \\
\hline 5 & $\begin{array}{l}\text { Berapa persentase } \\
\text { kemudahan } \\
\text { memasukkan jumlah } \\
\text { editor untuk melihat } \\
\text { hasil jadwal. }\end{array}$ & 90 & $\begin{array}{l}\text { Sudah sangat } \\
\text { terjangkau untuk } \\
\text { melihat jadwal } \\
\text { langsung. }\end{array}$ \\
\hline 6 & $\begin{array}{l}\text { Berapa persentase } \\
\text { untuk mengubah, dan } \\
\text { hapus masukkan data } \\
\text { yang sudah masuk. }\end{array}$ & 70 & $\begin{array}{c}\text { Belum ada menu } \\
\text { hapus sehingga } \\
\text { menyulitkan. }\end{array}$ \\
\hline 7 & $\begin{array}{c}\text { Berapa persentase } \\
\text { tingkat kecepatan } \\
\text { dalam menentukan } \\
\text { jadwal. }\end{array}$ & 75 & $\begin{array}{c}\text { Perlu reload } \\
\text { halaman saat } \\
\text { lihat jadwal. }\end{array}$ \\
\hline 8 & $\begin{array}{l}\text { Berapa persentase } \\
\text { aplikasi ini dibanding } \\
\text { proses manual dalam } \\
\text { penjadwalan. }\end{array}$ & 90 & $\begin{array}{c}\text { Lebih baik } \\
\text { daripada proses } \\
\text { pengolahan } \\
\text { jadwal secara } \\
\text { manual. }\end{array}$ \\
\hline 9 & $\begin{array}{l}\text { Berapa persentase } \\
\text { kemudahan dalam } \\
\text { keluar dari aplikasi }\end{array}$ & 90 & $\begin{array}{l}\text { Sudah cukup } \\
\text { baik karena } \\
\text { sangat mudah } \\
\text { keluar dari } \\
\text { aplikasi. }\end{array}$ \\
\hline & Persentase & \multicolumn{2}{|c|}{$\frac{770}{9}=86 \%$} \\
\hline
\end{tabular}

\section{DAFTAR PUSTAKA}

EFFRIANDI, E., ZENDA, Z. dan RACHMANSYAH, R., 2010. Rancang Bangun Aplikasi Penjadwalan Shift Kerja Lembur Menggunakan Algoritma Ant Colony Optimization (Studi Kasus : Pusri 1b). 1:1-12.

CHEN, C., NENG, W. dan ZHANG, J., 2013. Ant Colony Optimization for Software Project Scheduling and Staffing with an Event-Based Scheduler. IEEE Transactions on Software Engineering 39(1):1-17.

HAEKAL, H., MUHAMAD, M. dan ELIYANI, E., 2017. Token-Based Authentication Using JSON Web Token on SIKASIR RESTful Web Service. 2016 International Conference on Informatics and Computing, ICIC 2016 (Icic):175-79.

LI, L., JENG, W., YEN, C., LIN, Y.S., TUNG, S.C. dan HUANG, S.M., 2018. JustIoT Internet of Things Based on the Firebase Real-Time Database. Proceedings - 2018 IEEE 
International Conference on Smart Manufacturing, Industrial and Logistics Engineering, SMILE 2018, 2018-Janua:43-47.

LIU, L.U., JING, J., CHEN, L., DUN,Y. dan DONG, G., 2008. The Research of Ant Colony and Genetic Algorithm in Grid Task Scheduling. Proceedings - 2008 International Conference on MultiMedia and Information Technology, MMIT 2008, 47-49.

LIU, L.U., KUAN, T., CHEN, Y.P. dan CHOU, J.H., 2014a. Developing a Multiobjective Optimization Scheduling System for a Screw Manufacturer: A Refined Genetic Algorithm Approach. IEEE Access, 2:356-64.

LIU, L.U., KUAN T., CHEN, Y.P. dan CHOU, J.H., 2014b. Solving Distributed and Flexible JobShop Scheduling Problems for a Real-World Fastener Manufacturer. IEEE Access, 2:15981606.

MELLADO, R., CUBILlOS, C. dan CABRERA, D., 2016. A Constructive Heuristic for Solving the Job- Shop Scheduling Problem. Ieee Latin America Transactions, 14(6):2758-63.

MONTENEGRO, J.A., PINTO, M., dan FUENTES, L., 2017. What Do Software Developers Need to Know to Build Secure Energy-Efficient Android Applications?. IEEE Access, 6:142850.

NOSHEEN, F., BIBI, S. dan KHAN, S., 2013. Ant Colony Optimization Based Scheduling Algorithm. 2013 International Conference on Open Source Systems and Technologies, 1822.

PARERA, P., SUNAN, S., SUKMANA, H.T. dan WARDHANI, L.K., 2016. Application of Genetic Algorithm for Class Scheduling (Case Study: Faculty of Science and Technology UIN Jakarta). 2016 4th International Conference on Cyber and IT Service Management, 1-5.

PRESSMAN, R.S., 2010. CS605-Software Engineering Practitioner's Approach.

WANG, W., HUIJUN, H. dan SINNEN, O., 2018. List-Scheduling versus Cluster-Scheduling. IEEE Transactions on Parallel and Distributed Systems, 29(8):1736-49.

WIDYAWATI, W. dan Universitas Banten Jaya Serang, 2018. Penerapan Algoritma Ant Colony Optimization ( Aco ) Pada Job Shop Scheduling Problem ( Jssp ) Di Pt . Siemens Indonesia ( Cilegon Factory ). 1(1). 
Halaman ini sengaja dikosongkan 